\title{
RAD51C Gene Mutation
}

National Cancer Institute

\section{Source}

National Cancer Institute. RAD51C Gene Mutation. NCI Thesaurus. Code C131480.

A change in the nucleotide sequence of the RAD51C gene. 